\title{
Aging In Teaching: What Does It Bring?
}

\author{
Honesto Odi Camino ${ }^{a}$ \\ ${ }^{a}$ Research Management Office,Polytechnic University of the PhilippinesUnisan, Quezon BranchUnisan, Quezon, Philippines \\ Email:ahocamino@pup.edu.ph
}

Article History: Received: 10 November 2020; Revised 12 January 2021 Accepted: 27 January 2021; Published online: 5 April 2021

\begin{abstract}
This descriptive-correlation study inquires on the influence of length of experience in teaching on the organization values and on the teaching-related emotions of 251 public school teachers in a rural district in Southern Luzon, Philippines. The respondents were conveniently selected (participants in a district-wide in-service training). Data gathering was done during an in-service training using two scales: a 30-item scale that measures their and their perception of their colleagues' and superiors' adherence to organizational values and a 75-item scale that measures their teaching-related emotions. Spearman Rank Correlation was used to test the direction and magnitude of relationship between variables. Findings suggest the need to consider the affective aspects of the teachers in policy and program making as well as institution-based professional development program for teachers.
\end{abstract}

Keywords:

\section{Introduction}

An adage says "Experience is the best teacher". Work experience equips a beginner with certain soft skills such as team working, communication skills and commercial awareness, all of which are sought after by employers, especially at a graduate level. Work experience also helps to differentiate oneself, an important thing to factor in when competition for jobs is so fierce (2011-2020, 2020). It is seen by many as a double edged sword. With work experience, there is the chance to gain valuable on the job training and inside knowledge of a job that one would not be able to achieve in a college course or learning establishment (Wormley, 2019). Work experience should primarily be seen as the chance to gain an insight into the working environment (Westcott, 2015). As an individual ages in his or her work, he/she finds the same work getting better ("Levels of Personality", 2020).

But recently, the topic of teacher experience is getting a lot of attention in educational debates (Di Carlo, 2010) thereby indicating that there are conflicting views on the importance and impact of teaching experience. Microsoft founder Bill Gates, for one, discounts the weight of teaching experience and advanced academic degree in determining how well as teacher performs. Earlier, US Secretary of Education Anne Duncan made a similar pronouncement disregarding teaching experience in ranking, promoting and compensating teachers. This appears to corroborate the assertion that teachers' advantage declines as they stay longer in the profession (South African Council on Education, 2010).

Stinebrickner (2001), on the other hand, contends that, in addition to graduate education, teaching experience is a significant determinant of teaching salary, which in turn, has a positive effect on teacher retention. This finds supports from Strauss (2010) who asserts that experience in classroom does matter. This is one of the few observable teacher characteristics that are consistently correlated with (student or pupil) achievement (Mujis et al., 2014; Di Carlo, 2012; Heck, 2009)). Jacobson (2016) and Rice (2010) found out that teachers with longer years of teaching experience tend to have lower level of burn-out. As employees, they tend to have fewer avoidable absences, are more committed to their work and are less likely to quit (Robbins, 2009).

Length of teaching experience was also found to have significant direct effect on teacher's self-efficacy (Guo et al., 2012; Klassen \& Chiu, 2010) in that it develops self-knowledge that grows stronger through the years

There is a wide range of findings on the relationship between years of teaching experience and student outcomes (Ladd \& Sorenson, 2017; Papay and Kraft, 2015; Wiswall, 2013; Chetty, Friedman, \& Rockoff, 2014; Johnson, 2012). Teaching experience is positively associated with student achievement gains throughout a teacher's career. Gains in teacher effectiveness associated with experience are most steep in teachers' initial years, but continue to be significant as teachers reach the second, and often third, decades of their careers (Blazar, 2016; Kini \& Podolsky, 2016). Other studies show a stronger positive relationship between teacher experience and student outcomes in some, but not all (Irvine, 2018) suggests that the typical teaching learning curve peaks in a 
teacher's first few years (estimated at year two for reading and year three for Math (Darling-Hammond, Hyler \& Gardner, 2017). Other studies, however, were not able to identify consistent and statistically significant associations between student achievement and teacher experience (Blomeke et al., 2016; Gustaffsson and Nilson 2016; Luschei \& Chudgar, 2011).

Length of experience in teaching was also found to significantly and directly bear on job satisfaction (Mocheche, Raburu \& Bosire, 2018). As teachers age in teaching, they tend to develop clearer idea of their vital role in the society (Devlin \& Samarawickrema, 2018). They also have a more intensifying orientation towards teaching career (Doyle, Seery \& Cantyl, 2016), 1996). More so, control over and better use of one's emotions tends to improve over time (Kumar \& Muniandy, 2012).

\subsection{The Present Study}

Evidences from studies conducted in the recent past point out that the influence of the length experience in teaching has been well researched especially on its influence on student achievement (Podolsky, Kini and Darling-Hammond, 2018), on professional development of teachers (Broad \& Evans, 2006), on teachers' pays (Ordway, 2020) and on becoming vested in the defined benefit aspect of retirement plans (Loeb, Miller \& Strunk, n. d.) but there is hardly a research on the influence of length of experience in teaching on teachers' emotions (Hayes, 2003) and teachers' value system. Hence, this study was proposed.

This study is anchored to the Disengagement Theory of Cumming and Henry (1961) which postulates that aging (in teaching) causes knowledge and skill to deteriorate. The subsidiary idea of the postulate is that aging (in teaching and in any other occupations) has negative psychosocial repercussions, emotions and value system included. On the other hand, the study is anchored to the assumption that as individuals gain life experiences, the more they become intellectually autonomous and prepared to cope with uncertainty, able to tolerate ambiguity and not be driven by fear into a rigid single solution approach to problems, are rational and can control their behavior in the light of foreseen consequences, are altruistic and enjoy doing for others, and who understand social forces and trends. The two basic processes of education, knowing and valuing, lead them to be adept in figuring out philosophical outlooks, distilling their values (Kolzow, 2014) and learning organizational citizenship (Obiora, Obiora \& Tokpu, 2014)); hence, this inquiry into the teachers' value system and teaching-related emotions.

\section{Methods and Materials}

\subsection{Research Design}

This quantitative study employed the descriptive survey design, the purpose of which was to identify the direction and measure the magnitude of the relationship of the length of experience in teaching to the organizational values and teaching related emotions of the respondents.

\section{Participants}

Two-hundred fifty one (251) public elementary school teachers (belonging to a district in a rural area in Southern Luzon, Philippines) who attended one session facilitated by the author during their week-long in-service served as respondents of the study. Majority of them were females (211 or $84 \%)$. Most of them were handling one grade level (213 or $85 \%$ ) while the rest were either teaching in two or more grade levels, teaching in multi-grade classes, teaching in alternative learning system or did not indicate any response. Their average length of experience in teaching is 9.20 years $\mathrm{SD}=8.78$, the shortest barely a year and the longest being 36 years.

\subsection{Data Gathering Instruments}

Measure of Demographic Profile. This measure comes in the form of checklist (to elicit information on the respondents' sex and classes being handled) and fill-in-the-blank (to elicit information on the respondents' ages).

Measure of Value System. The researcher adopted the 10-item 5-point Likert-type questionnaire (strongly encourage it to strongly discourage as response anchor) of Robbins (2005) which was modified into 30 items such a way that teacher respondent would answer the question from his/her own viewpoint and from his/her perception of the viewpoint of his/her colleagues and immediate superior. Table 1 shows the psychometric properties of this scale as computed (based on the actual data of the study) using SPSS version 13. Results show that the whole scale and its subscales possess good internal reliability $(0.813 \leq \alpha \leq 0.943)$. More so, Table 1 displays the the concordance of each subscales of Value System with each other. Thirty seven out of 45 coefficients $(82.22 \%)$ were found to be significant at .01 level, suggesting that the subscales correlate well with each other (Kolotkin, Head \& Brookheart, 1997) and possess a good convergent validity.

Measure of Teaching-Related Emotions. The researcher adopted the Academic Emotion Questionnaire (AEQ) of Pekrun et al. (2005) whose items were contextualized in the field of teaching. It is a 75-item 5-point 
Liker-Type scale, the response options ranging from most of the time true of me to most of the time not true of me. It measures three positive and five negative academic emotions. A recent study (Lumiqued, 2012) established the model fit indices as follows: CFI $>.95$ and RMSEA $<.05$, indicating the goodness of fit of the instrument.

The current study was able to establish the internal consistency of the whole instrument as well as its subscales. The coefficients range from $0.741 \leq \alpha \leq 0.967$, indicating a good internal consistency. Construct validity indices showing the concordance among the positive emotion subscales (Enjoyment, Hope and Pride) range from $0.321 \leq \mathrm{r}_{\mathrm{xy}} \leq 0.481$, prob. $<0.01$. This indicates that these subscales correlate or converge well with each other (Kolotkin, Head \& Brookheart, 1997). The negative emotion subscales (Anger, Anxiety, Shame, Hopelessness and Boredom) also correlate well with each other $\left(.430 \leq r_{x y} \leq .729\right.$, prob. $\left.\leq .01\right)$. Finally, the evidences of the discriminant validity of the measure are shown by coefficients of concordance among the positive emotion subscales and the negative emotion subscales. As expected,coeffciients are negative and insignificant ($.09 \leq \mathrm{r}_{\mathrm{xy}} \leq-.115$, prob. $\left.>.05\right)$ or if significant, the coefficients are noticeably smaller $\left(-.154 \leq \mathrm{r}_{\mathrm{xy}} \leq-.111, .01 \leq \mathrm{p} \leq\right.$ $.05)$ when compared to their indices of convergent validity (Hubley, 2014).

Table 1

Reliability and Construct Validity Indices of the Research Instruments

\begin{tabular}{|c|c|c|c|c|c|c|c|c|c|c|c|}
\hline \multirow{2}{*}{$\begin{array}{c}\text { Subscales/Whole Scale } \\
\text { Value System } \\
\end{array}$} & \multirow{2}{*}{$\begin{array}{c}\begin{array}{c}\text { Cronbach's alpha } \\
\text { (and number of } \\
\text { items) }\end{array} \\
\end{array}$} & \multicolumn{10}{|c|}{ Construct Validity Indices } \\
\hline & & (1) & (2) & (3) & (4) & (5) & (6) & (7) & (8) & (9) & (10) \\
\hline (1) Candor or Openness & $0.849(3)$ & $x x$ & & & & & & & & & \\
\hline (2) Organizational Pride & $0.864(3)$ & $.559^{*}$ & $x x$ & & & & & & & & \\
\hline (3) Performance or Excellence & $0.813(3)$ & $.407^{*}$ & $.469^{*}$ & $x x$ & & & & & & & \\
\hline (4) Teamwork or Communication & $0.909(3)$ & $.447^{*}$ & $.528^{*}$ & $.454^{*}$ & $x x$ & & & & & & \\
\hline (5) Leadership or Supervision & $0.835(3)$ & $.290^{*}$ & $.283^{*}$ & $.342^{*}$ & $.422 *$ & $x x$ & & & & & \\
\hline (6) Cost Effectiveness & $0.874(3)$ & $.486^{*}$ & $.455^{*}$ & $.463^{*}$ & $.576^{*}$ & $.405^{*}$ & $x x$ & & & & \\
\hline (7) Colleague or Associate Relations & $0.874(3)$ & $.448^{*}$ & $.457^{*}$ & $.341^{*}$ & $.481^{*}$ & $.322 "$ & $.533^{*}$ & $x x$ & & & \\
\hline (8) Client Relations & $0.822(3)$ & $.309^{*}$ & $.386^{*}$ & $.194^{*}$ & $.444^{*}$ & $.333^{*}$ & $.429^{*}$ & $.528^{*}$ & $x x$ & & \\
\hline (9) Innovations or Creativity & $0.943(3)$ & -0.041 & -0.021 & 0.092 & -0.042 & $.307^{*}$ & 0.100 & 0.023 & 0.109 & $x x$ & \\
\hline (10) Training and Development & $0.887(3)$ & $.406^{*}$ & $.427^{*}$ & $.295^{*}$ & $.434^{*}$ & $.292^{*}$ & $.452 *$ & $.563^{*}$ & $.476^{*}$ & 0.089 & $x x$ \\
\hline (11) Whole Scale - Value System & $0.917(3)$ & & & & & & & & & & \\
\hline Emotions & & (1) & (2) & (3) & (4) & $(5)$ & (6) & (7) & (8) & (9) & \\
\hline (1) Enjoyment & $0.830(10)$ & $x x$ & & & & & & & & & \\
\hline (2) Hope ${ }^{b}$ & $0.797(5)$ & $.481^{*}$ & $x x$ & & & & & & & & \\
\hline (3) Pride & $0.741(6)$ & $.358^{*}$ & $.321^{*}$ & $x x$ & & & & & & & \\
\hline (4) Anger & $0.930(9)$ & -0.100 & $-.181^{*}$ & 0.097 & $x x$ & & & & & & \\
\hline (5) Anxiety & $0.911(11)$ & $-.176^{*}$ & $-.170^{*}$ & 0.069 & $.543^{*}$ & $x x$ & & & & & \\
\hline (6) Shame & $0.922(11)$ & -0.104 & $-.161^{\circ}$ & 0.026 & $.527^{*}$ & $.657^{*}$ & $x x$ & & & & \\
\hline (7) Hopelessness & $0.905(11)$ & -0.115 & -0.114 & -0.053 & $.430^{*}$ & $.460^{*}$ & $.530^{*}$ & $x x$ & & & \\
\hline (8) Boredom & $0.967(11)$ & $-.154^{\circ}$ & -0.090 & -0.017 & .524 & $.492^{*}$ & $.562 *$ & $.729^{*}$ & $x x$ & & \\
\hline (9) Whole Scale - Emotions & $0.942(75)$ & & & & & & & & & & \\
\hline
\end{tabular}

${ }^{a} \alpha$ coefficient between 0.65 and 0.8 (or higher in many cases); $\alpha$ coefficients that are less than 0.5 are usually unacceptable (https://data.library.virginia.edu/using-and-interpreting-cronbachs-alpha/)

b original Cronbach's alpha was 0.456 (based on 6 items) but the removal of item 1 of the subscale increased the coefficient to 0.797

note: Negative coefficients of construct validity are discriminant validity indices and demonstrated by evidence that measures of constructs that theoretically should not be highly related to each other and are, in fact, not found to be highly correlated to each other. Practically speaking, discriminant validity coefficients should be noticeably smaller in magnitude than convergent validity coefficients.

\section{Data Analysis}

The researcher conducted an exploratory data analysis to test the normality of the data and to identify appropriate the statistical test considering its normality of the data distribution. Results are shown on Table 2 and they suggest that the data set departs from normality. A Kolmogorov-Smirnov test indicates that the whole scales as well as their respective subscales do not follow a normal distribution, $\mathrm{D}(242)=.121 \leq \mathrm{D} \leq .298, \mathrm{p}<.000$ (Field, 2000). In addition, a Shapiro-Wilk test indicates a significant departure from normality, $\mathrm{W}(242)=.635 \leq$ $\mathrm{W} \leq .949, \mathrm{p}<.000$ (van den Berg, n. d.). Therefore, a nonparametric statistical test is appropriate and in this instance, it is the Spearman Rank Correlation Coefficient.

Table 2 
Test of the Normality of the Data Set

\begin{tabular}{|c|c|c|c|c|c|c|}
\hline \multirow{3}{*}{ SUBSCALES } & \multicolumn{6}{|c|}{ Normality Statistics } \\
\hline & \multicolumn{3}{|c|}{ Kolmogorov-Smirnov $^{\mathrm{a}}$} & \multicolumn{3}{|c|}{ Shapiro-Wilk } \\
\hline & Statistic & df & Sig. & Statistic & df & Sig. \\
\hline \multicolumn{7}{|l|}{ VALUE SYSTEM } \\
\hline Candor or Openness & 0.298 & 242 & 0.000 & 0.711 & 242 & 0.000 \\
\hline Organizational Pride & 0.209 & 242 & 0.000 & 0.849 & 242 & 0.000 \\
\hline Performance or Excellence & 0.182 & 242 & 0.000 & 0.848 & 242 & 0.000 \\
\hline Teamwork or Communication & 0.225 & 242 & 0.000 & 0.836 & 242 & 0.000 \\
\hline Leadership or Supervision & 0.248 & 242 & 0.000 & 0.871 & 242 & 0.000 \\
\hline Cost Effectiveness & 0.164 & 242 & 0.000 & 0.866 & 242 & 0.000 \\
\hline Colleague or Associate Relations & 0.239 & 242 & 0.000 & 0.819 & 242 & 0.000 \\
\hline Client Relations & 0.233 & 242 & 0.000 & 0.807 & 242 & 0.000 \\
\hline Innovations or Creativity & 0.195 & 242 & 0.000 & 0.910 & 242 & 0.000 \\
\hline Training and Development & 0.285 & 242 & 0.000 & 0.785 & 242 & 0.000 \\
\hline \multicolumn{7}{|l|}{$\begin{array}{l}\text { TEACHING-RELATED } \\
\text { EMOTIONS }\end{array}$} \\
\hline Enjoyment & 0.136 & 242 & 0.000 & 0.941 & 242 & 0.000 \\
\hline Hope & 0.184 & 242 & 0.000 & 0.914 & 242 & 0.000 \\
\hline Pride & 0.121 & 242 & 0.000 & 0.949 & 242 & 0.000 \\
\hline Anger & 0.159 & 242 & 0.000 & 0.879 & 242 & 0.000 \\
\hline Anxiety & 0.126 & 242 & 0.000 & 0.769 & 242 & 0.000 \\
\hline Shame & 0.126 & 242 & 0.000 & 0.819 & 242 & 0.000 \\
\hline Hopelessness & 0.135 & 242 & 0.000 & 0.841 & 242 & 0.000 \\
\hline Boredom & 0.240 & 242 & 0.000 & 0.635 & 242 & 0.000 \\
\hline
\end{tabular}

a. Lilliefors Significance Correction

\section{Results}

Descriptive summary using mean and standard deviations for the 10 indicators of the value system and the 8 indicators of the teaching-related emotions of the teacher respondents were computed. Likewise, correlation coefficients between the length of experience in teaching and value system as well as teaching-related emotions were also obtained.

\section{Table 3}

Descriptive Summary of the Value System and Teaching-Related Emotions of the Teacher Respondents

\begin{tabular}{lll}
\hline INDICATORS & Mean & Std. Deviation \\
\hline Value System $^{\text {a }}$ & & \\
Candor or Openness & 4.62 & 0.55 \\
Organizational Pride & 4.51 & 0.58 \\
Performance or Excellence & 4.38 & 0.63
\end{tabular}




$\begin{array}{lll}\text { Teamwork or Communication } & 4.48 & 0.60 \\ \text { Leadership or Supervision } & 4.06 & 0.94 \\ \text { Cost Effectiveness } & 4.36 & 0.61 \\ \text { Colleague or Associate Relations } & 4.55 & 0.63 \\ \text { Client Relations } & 4.52 & 0.58 \\ \text { Innovations or Creativity } & 3.45 & 1.27 \\ \text { Training and Development } & 4.50 & 0.65\end{array}$

Teaching-Related Emotions ${ }^{\mathrm{b}}$

Enjoyment

Hope

Pride

Anger

Anxiety

Shame

${ }^{\mathrm{a}} 1.00-1.79=$ strongly discourage it

it

$1.80-2.59=$ discourage it
$3.40-4.19=$ simply encourage it

$$
4.20-5.00=\text { strongly encourage }
$$

$2.60-3.39=$ consider it unimportant

${ }^{\mathrm{b}} 1.00-1.74=$ most of the time not true of me

$1.75-2.49=$ occasionally not true of me

\section{$2.50-3.24=$ occasionally true of me}

$3.25-4.00=$ most of the time

true of me

Table 3 shows the means and standard deviations for the 10 subscales of the value system. Mean scores range from the lowest of 3.45 for innovation or creativity $(\mathrm{SD}=1.27)$ to the highest of 4.62 for openness or Candor $(\mathrm{SD}=0.55$ ). This evidences that teacher respondents moderately uphold the importance of spontaneous creativity, ingenuity and information processing. Creativity and innovation enable a person to look at all sides of a problem or an issue and comes up with a solution that is entirely new and interesting (Schwarz, 2015) and has been highlighted as essential skills for the $21^{\text {st }}$ century, especially if one has to consider that both skills can promote human potential by eliciting positive aspects of the individual (Nakano \& Wechsler, 2018). While teachers vary in their beliefs about creativity (Bereczki \& Kampati, 2018), its application to the teaching learning process yields results which are more or less the same as evidenced by several recent studies such as those by Saad (2019), Study International Staff ( 2019 and Davis (2018) among others.

Recently, candor or openness was considered to be the new metric of corporate leadership (which in the past was creating wealth for the investors) and this means the extent to which executives create organizations that are economically, ethically, and socially sustainable (O'Toole \& Bennis, 2009). Candor implies that ideas put forth will be dealt with in an honest and straightforward way (Quick, 2006).. Candor was found to be positively and significantly related to students' interest in lesson and their focusing of attention to the lesson and the teaching process (Reber, Ridge \& Down, 2017). Teaching is a matter of building credibility to others while exposing the teacher to vulnerability and one means of embracing this tension between expressing vulnerability and appearing credible 'intellectual candour', an improvisational expression of doubts, thoughts and problems with the dual purpose of learning and promoting others' learning (Molloy \& Bearman, 2018). The remaining eight values were perceived to be strongly encouraged, $(\mathrm{M}=4.06 \leq \mathrm{M} \leq 4.55, \mathrm{SD}=0.55 \leq \mathrm{SD} \leq 1.27)$. Research literature provide evidence that these eight values were found to be influencing the dynamics in the school system such as the 
influence of concern for colleague on fostering a sense of ownership and purpose in the way that teachers approach their jobs as teachers (Eller \& Eller, 2013) and how it manifests in passion in teaching which consequently influence teachers' performance and motivation as well as successful student learning (Mart, 2013) among others.

Considering teaching-related emotions, the teacher respondents reported all the three positive emotions to be true of them most of the time: Enjoyment $(M=3.65, S D=0.39)$, Hope $(M=3.60, S D=0.44)$ and Pride $(M=$ $3.34, \mathrm{SD}=0.53)$. Four of the five negative emotions were reported to be occasionally not true of them with Shame leading $(\mathrm{M}=2.22, \mathrm{SD}=1.08)$ while Anger was reported to be not true of them most of the time $(\mathrm{M}=1.71, \mathrm{SD}=$ $0.69)$,

The role of emotions in the teaching-learning process cannot be relegated to the background. Previous research highlighted that emotions are; 1) essential for student learning, the quality of teaching and the well-being of both the teachers and the learners (Mendzheritskaya \& Hansen, 2019), 2) are prime drivers of students' and academics' engagement, performance, and interpersonal perceptions (Pekrun, 2019). and 3) have an impact on student's use of technology (Stefan, Markus \& Glaiser-Zikuda, 2019). Emotions played an important role in teachers' engagement in professional development program and triggered changes in teachers' thinking and implementation of their science teaching practices. Positive correlations were found among teachers' motivations and emotions about their professional development experience, as well as changes to their teaching practices (Thomson \& Turner, 2019). Positive emotions such as Enjoyment of teaching can positively impact student enjoyment of learning, energize teachers in their desire to improve the quality of their instruction, and protect teachers against burn-out and attrition (Frenzel et al., 2016). Teachers' negative emotions like anxiety was found to alter girls' gender ability beliefs in such a way that their mathematical scores are inferior to those other female students whose math teachers do not present anxiety toward the subject matter (Ruiz, 2016). Negative emotions from the teacher (specifically anger) may interfere with the children's ability to process emotional information (Morris et al., 2013)

\section{Table 4}

Spearman Rank Correlations of Length of Experience in Teaching and Value System

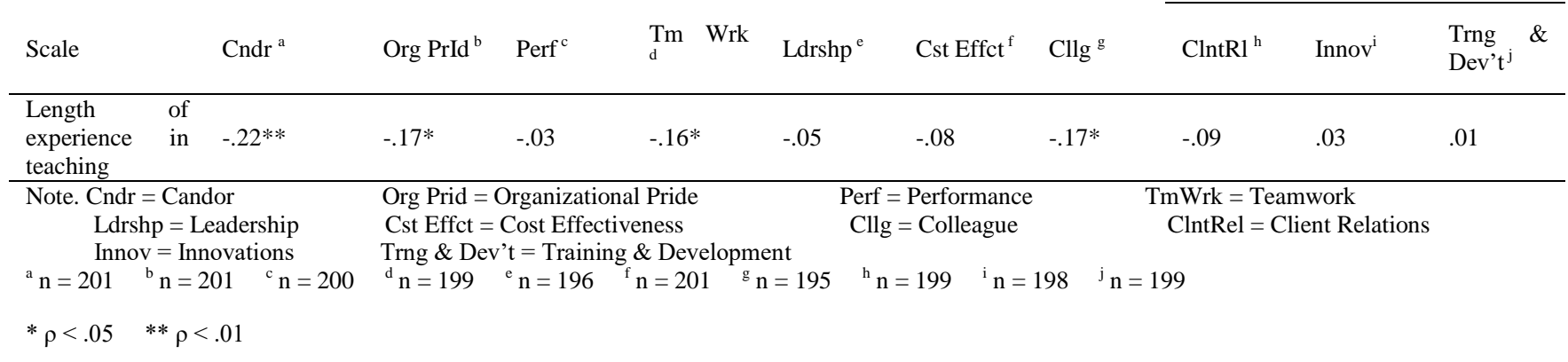

Four of the ten values significantly correlated with the length of experience in teaching. The strongest Spearman rank correlation coefficient for the length of experience in teaching was with Candor: $r(199)=-.22, \rho<$ .01.This was followed by Colleague: $r(193)=-.17, \rho<.05$. Next was Organizational Pride: $r(199)=-.17, \rho<.05$. Finally, the length of experience significantly correlated with Teamwork at $r(197)=-.16, \rho<.05$. Therefore, evidences from the sample partially rejected the hypothesis which states that the length of the teaching experience of teacher does not significantly relate with their value system.

\section{Table 5}

Spearman Rank Correlations of Length of Experience in Teaching and Teaching Related Emotions

\begin{tabular}{|c|c|c|c|c|c|c|c|c|c|}
\hline Scale & & $\begin{array}{l}\text { Enjoy- } \\
\text { ment }^{\text {a }}\end{array}$ & Hope $^{b}$ & Pride $^{c}$ & Anger ${ }^{d}$ & Anxiety ${ }^{\mathrm{e}}$ & Shame ${ }^{f}$ & $\begin{array}{l}\text { Hopeless- } \\
\text { ness }\end{array}$ & $\begin{array}{l}\text { Bore- } \\
\text { dom }^{h}\end{array}$ \\
\hline $\begin{array}{l}\text { Length } \\
\text { experience } \\
\text { teaching }\end{array}$ & $\begin{array}{l}\text { of } \\
\text { in }\end{array}$ & 0.06 & -0.04 & 0.10 & $0.17 *$ & 0.12 & $0.20 * *$ & $0.18 *$ & 0.12 \\
\hline
\end{tabular}

${ }^{\mathrm{a}} \mathrm{n}=201 \quad{ }^{\mathrm{b}} \mathrm{n}=200 \quad{ }^{\mathrm{c}} \mathrm{n}=201 \quad{ }^{\mathrm{d}} \mathrm{n}=201 \quad{ }^{\mathrm{e}} \mathrm{n}=201 \quad{ }^{\mathrm{f}} \mathrm{n}=201 \quad{ }^{\mathrm{g}} \mathrm{n}=200 \quad{ }^{\mathrm{h}} \mathrm{n}=201$

$* \rho<.05 \quad * * \rho<.01$

Table 5 shows that the length of experience in teaching correlated significantly with three of the five negative teaching-related emotions. The strongest Spearman Rank Correlation Coefficient was with Shame: $r(199)=.20, \rho$ $<.01$. Length of experience in teaching also correlated significantly with Hopelessness: $r(198)=.18, \rho<.05$ and with Anger: $r(199)=.17, \rho<.05$. None of the positive teaching-related emotions significantly correlated with 
length of experience in teaching. Evidences from the sample partly rejected the null hypothesis which states that the length of experience is teaching does significantly correlated with teaching-related emotions.

\section{Discussion and Conclusions}

The present study's alternate hypothesis states that the length of experience in teaching significantly relates with the organizational values and teaching-related emotions. Statistical evidences from the sample of the study partly confirm the hypothesis. The length of experience in teaching is inversely but significantly related to the values Candor, Colleague, Organizational Pride and Teamwork.

Recently, candor or openness was considered to be the new metric of corporate leadership (which in the past was creating wealth for the investors) and this means the extent to which executives create organizations that are economically, ethically, and socially sustainable (O'Toole \& Bennis, 2009). Candor implies that ideas put forth will be dealt with in an honest and straightforward way (Quick, 2006). Candor was found to be positively and significantly related to students' interest in lesson and their focusing of attention to the lesson and the teaching process (Reber, Ridge \& Down, 2017). Teaching is a matter of building credibility to others while exposing the teacher to vulnerability (or bullying by students, parents, co-teachers among others) and one means of embracing this tension between expressing vulnerability and appearing credible 'intellectual candour', an improvisational expression of doubts, thoughts and problems with the dual purpose of learning and promoting others' learning (Molloy \& Bearman, 2018). Candor is considered one of the ten universal traits of an effective educational leadership.

The current study found out that as the teachers stay longer in teaching, the less they become candid and less open to new experiences. This finding confirms previous studies such as those of Donellan \& Lucas $(2011,2008)$. There is this tendency, as they age, to be more complacent with what they have had for quite a long period of time and see things as what they have been in the past. This confirms what Pikence's (2010) study found out. Teachers who have 1 to 5 years of teaching experience value most the sense of accomplishment among others compared to those who have 6 to 15 and those who have 16 or more years of experience in teaching. It can be construed that the sense of accomplishment emanates from being open to new experiences (Nie $\beta$ \& Zacher, 2015 which appears to diminish over time. However, the finding of the current study runs contrary to that of Taneva, Arnold and Nicolson (2016).

Concern for colleagues' well-being is not only about their physical health. Colleagues' well-being holds a much bigger significance in the workplace -- how employees envision their future, goals, overall outlook and attitude (Huhman, 2016). Concern for colleague was found to be beneficial to the workplace as it promotes teamwork, leads to more amicable settle of conflicts and strengthening mutuality of interest as Rajgopal (201) suggests. In the current study, concern for colleagues seems to be diminishing as the teacher respondents age in teaching, however, there is not much empirical support to this finding. In fact, it disconfirms the finding that older workers are more likely to want opportunities to work in teams, collaborate with colleagues or have a lot of contact with clients or members of the public (Marvell \& Cox, 2017). For many older workers, one of the main benefits from working in later life is the social side of work: contact with others, team-based working and forming professional and personal relationships formed through work (CIPD, 2014; Boot et al, 2016; Oude Hengel et al, 2012; Duffield et al, 2015; YouGov, 2015; Buckle, 2015; Boumans et al, 2011; Carmichael et al, 2013).

Perhaps, this tendency of diminishing concern for colleagues (as the current study pointed out) springs from the self-perception of increasing uselessness due to decreasing physical and cognitive abilities over time which is reinforced by the culture of Ageism practices in the organization such as offering learning opportunities offered to younger employees - not older ones, overlooking or passing over older workers for challenging assignments, leaving out older worker of client meetings or company activities, a spoken or unspoken assumption that aging workers are not entitled to take time off for family commitments because they do not have young kids at home anymore, disparaging comments and remarks about age and aging workers being passed over for raises and promotions; Authenrieth, n. d.). In addition, this finding maybe accounted for by the so called Intergenerational Divide (between Generation X, those born between 1965 and 1977, and the millennials, born after that) which is increasingly becoming evident in the workplace and where once revered older workers and novice younger employees are less likely to form mentor-mentee relationships (Wessel, 2015). Intergenerational divide is also characterized by the divergence of values between older workers characterized by work ethics (Emma, 2019) and work wisdom distilled by long years of experience and younger workers' digital savviness that gives them the confidence that they can know almost everything in their sphere of interest as long as there is gadget and connectivity that is reinforced by the Do-It-Yourself culture.

Organizational Pride, at its simplest, is having high esteem in a respectful manner for the organization an employee is part of and it is or must be seen at all levels of any organization (McGillicuddy, 2010). It has direct, positive effect on commitment to customer service and creativity as found out by Goutheir and Rhein (2010) and 
to the intent to remain with the organization (Helm, 2013). The current study pointed out that there is an inverse relationship between length of experience in teaching and organizational pride which confirms the study of Gardner and Macky (2012) and Twenge, Campbell, Hoffman and Lance (2010), However, there is not much literature running contrary to the finding of the study save for the one conducted by Federico (1996). This confirms Ferreira-Vasconcelos' (2017) finding that there are scant research efforts toward aging theorizing, particularly concerning to the usage of older workers'value, i.e., focusing on their potentialities, capabilities and skills.

Why organizational pride declines with age as this study found out maybe attributed to the postulate of the Disengagement Theory of Cummins and Henry (1961) which states that as one ages, one's abilities will likely deteriorate over time and as a result, every person will lose ties to others in his or her society including his/her connection to work. As an offshoot, the sense of personal accomplishment derived from work also decreases. In addition, the practice of Ageism (Psychology Today, 2019; Authenrieth, n. d) as cited earlier in this paper, may account for this finding.

\section{Length of Experience in Teaching in Relation to Teaching-Related Emotions}

The length of experience in teaching was found to be directly proportional to Shame. As a self-conscious emotion, shame informs a person of an internal state of inadequacy, unworthiness, dishonor, regret, or disconnection (Lamia, 2011); inadequacy that may stem from external sources such as some observers' declaration that experienced teachers are not needed and their (observers) approval of the "greening " of the teacher force (Education, 2013) and/or from internal sources such as comparing the self with others who they believe are better than they are (Psychology Today, n. d.) This finding of the current study confirms previous studies which found out that the feeling that they, the older teachers, are not as adept as others especially the younger ones appears to be another source of shame, especially when it comes to the use of technology in the teaching learning process (Lee et al., 2019; Howard \& Mosejko, 2015; Czaja et al., 2006).

Data from the sample also suggests that hopelessness is an outcome of aging. There is a significant relationship between the two construct. The declining physical strength and sensory sensitivity leads to decreased interaction with the social system, increasing preoccupation with the irreversible physical changes occurring in the body and the imminence of death (Lange \& Grossman, n. d.). This is consistent with the idea of the Disengagement Theory of Cumming and Henry (1961) which states that society fosters this disengagement by providing fewer opportunities for older adults to participate in the workforce and in social situations (The Psychology of Aging, $\mathrm{n}$. d.) Declining physical health exposes the elderly to greater vulnerability that generates the emotion of hopelessness (Hartmann et al., 2018). Furthermore, the decline in knowledge and skills brought about by aging is rapidly precipitated or reinforced by the mandatory retirement age.

Years of experience in teaching was also found to be directly proportional to the emotion of anger among the teacher respondents. Workers, especially women, in their 40s scored significantly higher on anger while at work compared to women from other age groups but no significant age differences were found in anger experienced at home (Thomas, 2002). Another study confirmed the finding that age is associated with anger but only if there is illness associated with aging (The Conversation, 2019). However, the finding of a study which found out that age is associated with lower anger (Shallcross, Ford, Floerke \& Mauss, 2013) and that anger regulation improves with age (Phillips, Henry, Hosie and Milne (2007) were not confirmed by this study.

\section{Limitations and Directions for Future Research}

The present study has several limitations which offer avenues for future investigations. First, due to time constraints, the sampling techniques used was non probabilistic, therefore, the sample was not representative of the population of the study. Findings of the study could not be generalized to the population. Future research may consider probability sampling as a technique. Second, the current study focused on teacher respondents in a rural area, therefore, the findings could not be generalized to teachers in urban and highly urbanized settings. Widening the geographical scope of the study may provide better perspectives in viewing the differences between teachers in rural and urban areas. The use of correlation technique is another limitation in that it cannot infer causality between the variables of the study. Future research may consider additional variables to provide a multifactorial explanation of the phenomenon of the study. In addition, the study was cross-sectional which limits the ability to infer causality. A longitudinal study may provide richer and more valid connections between the constructs which could not be observed in a short period of time. Finally, the data generated by the study are self-reports. Future study may consider additional data such as those gathered by the use of interviews with the subjects, immediate heads, colleagues and students.

\section{Implications}

The findings of the present study indicate that school authorities and other pertinent sectors need to pay attention to and address the phenomenon in question. Proactive attention to the implications of the findings of the 
study suggests that aging in teaching is not simply a matter of personal concern of individual teachers. In addition, findings suggest that preretirement programs may need to be instituted and these should focus on the holistic view and functional nature of aging. Experiences that accumulate in the course of teaching can be harnessed towards developing growth activities that will help in the development of positive image or sense of self or ego integrity as Erikson calls it. Likewise, post-retirement activities managed by the concerned agencies can be developed towards actively engaging the retired teachers in tasks that will optimize their engagement in the mainstream of the society. Media and literature and other vehicles of culture may need to cultivate sensitivity in portraying the phenomenon of aging. The negative affect and images that gradually build up due to aging may find reinforcement, and may even be intensified, by advertisements that are capitalizing on youthfulness, vigor and physical strength and are insensitive to the concerns of aging persons. Finally, regulatory bodies concerning aging persons may need to review the rationality of existing statutes such as retirement laws as they discriminate against the sector in question. Observations point out that many individuals past the retirement age are still capable of doing particular jobs.

\section{References}

Anger linked to illness in old age. (2019, 5 9). Retrieved from The Conversation: https://theconversation.com/anger-linked-to-illness-in-old-age-116550

Autenrieth, N. (n.d.). 6 Signs of Ageism in the Workplace - and How to Handle It. Retrieved from TopResume: https://www.topresume.com/career-advice/signs-of-ageism-in-the-workplace

Boot, C., de Kruif, A., Shaw, W., van der Beek, A., Deeg, D., \& Abma, T. (2016, 6 1). Factors Important for Work Participation Among Older Workers with Depression, Cardiovascular Disease, and Osteoarthritis: A Mixed Method Study. Journal of Occupational Rehabilitation, 26(2), 160-172.

Boumans, N., De Jong, A., \& Janssen, S. (2011, 1 1). Age-differences in work motivation and job satisfaction. the influence of age on the relationships between work characteristics and workers' outcomes. International Journal of Aging and Human Development, 73(4), 331-350.

Bullough, R. (2005). Teacher Vulnerability and Teachability: A Case Study of a Mentor and Two Interns. Teacher Education Quarterly.

Carmichael, F., Hulme, C., \& Porcellato, L. (2013). Older age and ill-health: Links to work and worklessness. International Journal of Workplace Health Management, 6(1), 54-65.

Czaja, S., Charness, N., Fisk, A., Hertzog, C., Nair, S., Rogers, W., \& Sharit, J. (2006, 6). Factors predicting the use of technology: Findings from the Center for Research and Education on Aging and Technology Enhancement (CREATE). Psychology and Aging, 21(2), 333-352.

Davis, L. (2018). Creative Teaching and Teaching Creativity: How to Foster Creativity in the Classroom. Retrieved from Psych Learning Curve: http://psychlearningcurve.org/creative-teaching-and-teachingcreativity-how-to-foster-creativity-in-the-classroom/

Department for Work and Pensions. (2015). Attitudes of the over 50s to Fuller Working Lives.

Donnellan, M., \& Lucas, R. (2008, 9). Age Differences in the Big Five Across the Life Span: Evidence From Two National Samples. Psychology and Aging, 23(3), 558-566.

Duffield, C., Graham, E., Donoghue, J., Griffiths, R., Bichel-Findlay, J., \& Dimitrelis, S. (2015, 3 1). Why older nurses leave the workforce and the implications of them staying. Journal of Clinical Nursing, 24(5-6), 824831.

Eller, J., \& Eller, S. (2013, 4). Working with Difficult Staff . The Principalship, 70(7).

Emma, L. (2019, 1 28). The Advantages of Mentoring in the Workplace. Retrieved from Chron: https://smallbusiness.chron.com/advantages-mentoring-workplace-18437.html

Ferreira-Vasconcelos, A. (2017). Older workers as a source of wisdom capital: broadening perspectives. Revista de Gestão, 25(1), 102-118.

Frenzel, A., Pekrun, R., Goetz, T., Daniels, L., Durksen, T., Becker-Kurz, B., \& Klassen, R. (2016, 7 1). Measuring Teachers' enjoyment, anger, and anxiety: The Teacher Emotions Scales (TES). Contemporary Educational Psychology, 46, 148-163.

Gardner, D., \& Macky, K. (2012). Generational differences: Something old, something new. In D. Gardner, \& K. Macky, Work and Quality of Life: Ethical Practices in Organizations (pp. 417-428). Springer Netherlands.

Gouthier, M., \& Rhein, M. (2011, 10). Organizational pride and its positive effects on employee behavior. Journal of Service Management, 22(5), 633-649.

Hartmann Júnior, J., Farias Fernandes, A., Pimentel de Medeiros, A., de Vasconcelos, C., de Amorim, L., Silveira de Queiroga, M., . . . Torres de Araújo, R. (2018, 7 10). Hopelessness in the elderly: a systematic review. MOJ Gerontology \& Geriatrics, 3(4). 
Helm, S. (2013, 12 1). A Matter of Reputation and Pride: Associations between Perceived External Reputation, Pride in Membership, Job Satisfaction and Turnover Intentions. British Journal of Management, 24(4), 542556.

Huhman, H. (2016). Show Employees You Care About Their Well-Being. Here are 5 Ways. Retrieved from Entrepreneur Asia Pacific: https://www.entrepreneur.com/article/282497

Lamia, M. (2011, 4 4). Shame: A Concealed, Contagious, and Dangerous Emotion. Retrieved from Psychology Today: https://www.psychologytoday.com/us/blog/intense-emotions-and-strong-feelings/201104/shameconcealed-contagious-and-dangerous-emotion

Lange, J., \& Grossman, S. (2018). Theories of Aging. In J. Lange, S. Grossman, \& K. Mauk (Ed.), Gerontological Nursing: Competencies for Care.

Lee, C., Czaja, S., Moxley, J., Sharit, J., Boot, W., Charness, N., \& Rogers, W. (2019, 1 9). Attitudes Toward Computers Across Adulthood From 1994 to 2013. Gerontologist, 59(1), 22-23.

Lucas, R., \& Donnellan, M. (2011, 10). Personality Development Across the Life Span: Longitudinal Analyses With a National Sample From Germany. Journal of Personality and Social Psychology, 101(4), 847-861.

(2014). Managing an age-diverse workforce Employer and employee views.

Marvell, R., \& Cox, A. (2017). What do older workers value about work and why? Institute for Employment Studies.

McGillicuddy, N. (n.d.). What is Organizational Pride? Retrieved from Joint Base Andrews: https://www.jba.af.mil/News/Commentaries/Display/Article/337996/what-is-organizational-pride/

Mendzheritskaya, J., \& Hansen, M. (2019, 10 3). The role of emotions in higher education teaching and learning processes. Studies in Higher Education, 44(10), 1709-1711. Routledge.

Morris, C., Denham, S., Bassett, H., \& Curby, T. (2013, 10). Relations Among Teachers' Emotion Socialization Beliefs and Practices and Preschoolers' Emotional Competence. Early Education and Development, 24(7), 979-999.

Nieß, C., \& Zacher, H. (2015, 6 25). Openness to Experience as a Predictor and Outcome of Upward Job Changes into Managerial and Professional Positions. (P. Roma, Ed.) PLOS ONE, 10(6), e0131115.

Online, R., Howard, S., Mozejko, A., Howard, S., \& Howard, S. (2015). Teachers: technology, change and resistance. Cambridge University Press.

O'toole, J., \& Bennis, W. (2009). A Culture of Candor.

Oude Hengel, K., Blatter, B., Geuskens, G., Koppes, L., \& Bongers, P. (2012, 10). Factors associated with the ability and willingness to continue working until the age of 65 in construction workers. International Archives of Occupational and Environmental Health, 85(7), 783-790.

Pekrun, R. (2019, 103 ). Inquiry on emotions in higher education: progress and open problems. Studies in Higher Education, 44(10), 1806-1811.

Phillips, L., Henry, J., Hosie, J., \& Milne, A. (2006, 5). Age, anger regulation and well-being. Aging and Mental Health, 10(3), 250-256.

Quick, G. (2006). Openness, Candor and Respect. Retrieved from Fast Company: https://www.fastcompany.com/919259/openness-candor-and-respect

Reber, J., Ridge, R., \& Downs, S. (2017, 6 12). Perceptual and behavioral effects of expectations formed by exposure to positive or negative Ratemyprofessors.com evaluations. (P. Walla, Ed.) Cogent Psychology, 4(1).

Rodrigo-Ruiz, D. (2016). Effect of Teachers' Emotions on Their Students: Some Evidence. Journal of Education \& Social Policy, 3(4)

Social Comparison Theory. (n.d.). Retrieved from Psychology Today International: https://www.psychologytoday.com/intl/basics/social-comparison-theory

Stephan, M., Markus, S., \& Gläser-Zikuda, M. (2019, 10 4). Students' Achievement Emotions and Online Learning in Teacher Education. Frontiers in Education, 4, 109.

Taneva, S., Arnold, J., \& Nicolson, R. (2016, 10 1). The Experience of Being an Older Worker in an Organization: A Qualitative Analysis. Work, Aging and Retirement, 2(4), 396-414.

The Evidence on Age Discrimination in the Workplace. (2019). Retrieved from Psyschology Today: https:/www.psychologytoday.com/us/blog/evidence-based-living/201901/the-evidence-age-discriminationin-the-workplace

Thomas, S. (2002). Age differences in anger frequency, intensity, and expression. Journal of the American Psychiatric Nurses Association, 8(2), 44-50.

Tuğrul Mart, Ç. (2013). A Passionate Teacher: Teacher Commitment and Dedication to Student Learning. International Journal of Academic Research in Progressive Education and Development, 2(1).

Twenge, J., Campbell, S., Hoffman, B., \& Lance, C. (2010). Generational differences in work values: Leisure and extrinsic values increasing, social and intrinsic values decreasing. Journal of Management, 36(5), 1117 1142.

Varona, F. (1996, 4 1). Relationship Between Communication Satisfaction and Organizational Commitment in Three Guatemalan Organizations. Journal of Business Communication, 33(2), 111-140. 
Wessel, R. (2015, 4 1). Bridging the intergenerational divide. Retrieved from BBC Worklife: https://www.bbc.com/worklife/article/20150331-whats-that-you-say-grandpa

What makes an effective leader in education? (n.d.). Retrieved from The University of Kansas School of Education: https://educationonline.ku.edu/community/what-makes-an-effective-leader

Why Experienced Teachers are Important - And What Can be Done to Develop Them. (n.d.). Retrieved from Scholars Strategy Network: https://scholars.org/contribution/why-experienced-teachers-are-important-andwhat-can-be-done-develop-them

Yochim, B., \& Woodhead, E. (2017). Psychology of Aging: A Biopsychosocial Perspective. (B. Yochim, \& E. Woodhead, Eds.) New York, NY: Springer Publishing Company. 